Proceeding of ICECRS, 1 (2016) 863-874

ISSN. 2548-6160

International Seminar on Generating Knowledge Through Research, UUM-UMSIDA, 25-27 October 2016, Universiti Utara Malaysia, Malaysia.

Available online: http://ojs.umsida.ac.id/index.php/icecrs

Article DOI: http://dx.doi.org/10.21070/picecrs.v1i1.603

\title{
KOMITMEN GURU DAN KEPUASAN KERJA GURU DI SEKOLAH MENENGAH HARIAN BERPRESTASI TINGGI DAN BERPRESTASI RENDAH DI DAERAH KOTA BHARU, KELANTAN
}

\author{
Rozi Mohamad \\ Dr. Abd Latif Kasim \\ Sofiah Zakaria \\ Faezah Mohd Nasir \\ Pusat Pengajian Pendidikan dan Bahasa Moden, Universiti Utara Malaysia
}

\begin{abstract}
ABSTRAK: Satudaripada bidang Keberhasilan Utama Negara (NKRA) yang terdapat dalam Pelan Transformasi Kerajaan (GTP) adalah untuk meningkatkan pencapaian akademik pelajar. Bagi merealisasikannya, guru perlu bertindak sebagai pemain utama dalam melaksanakan pelbagai dasar dan program yang terkandung dalam GTP tersebut. Selain mengajar, dasar dan program tersebut datang bersama dengan pelbagai tugasan yang perlu dipikul guru. Tugasan yang bertambah akan menimbulkan masalah yang membawa kepada meningkatnya tekanan kerja, mempengaruhi komitmen dan kepuasan kerja guru. Sehubungan itu, tujuan kajian ini adalah untuk mengenal pasti tahap komitmen guru dan tahap kepuasan kerja gurudi sekolah menengah (SMK) harian berprestasi tinggi dan SMK harian berprestasi rendah. Kajian juga bertujuan mengkaji hubungan antara komitmen guru dengan kepuasan kerja dalam kalangan mereka. Di samping itu, kajian juga mengkaji bagaimana faktor demografi seperti jantina, umur dan pengalaman mengajar boleh mempengaruhi komitmen dan kepuasan kerja. Populasi kajian adalah guru-guru yang mengajar di enam buah sekolah menengah harian dalam daerah Kota Baharu, Kelantan. Sampel seramai 200 orang dipilih menggunakan kaedah persampelan rawak mudah. Dua set instrumen soal selidik telah digunakan untuk memungut data kajian iaitu Soal Selidik Skala Komitmen Guru (SKG) yang dibangunkan oleh Thien, Nordin Abd Razak dan Ramayah (2014), dan Job Satisfaction Survey (JSS)yang dibangunkan oleh Spector (1997). Analisis deskriptif dan inferensi dijalankan menggunakan perisian Statistical Package for Social Science (SPSS) versi 21.0. Dapatan kajian menunjukkan tahap komitmen dan kepuasan kerja guru berada pada tahap tinggi. UjiankorelasiPearson pula menunjukkan terdapat hubungan positif yang signifikan antara komitmen dengan kepuasan kerja guru di kedua-dua kategori sekolah.
\end{abstract}

KATA KUNCI: Skala Komitmen Guru, komitmen guru, kepuasan kerja guru, SMK harian prestasi tinggi, SMK harian prestasi rendah.

\section{PENGENALAN}

Sekolah-sekolah kerajaan di Malaysia adalah merupakan sekolah yang mengamalkan sistem pengurusan berpusat. Sehubungan itu penyediaan prasarana, kemudahan dan kelengkapan sekolah, penempatan guru, nisbah guru murid, bekalan buku teks, kurikulum mata pelajaran, peperiksaan termasuk pelantikan pengetua dan penolong-penolong kanan semuanya diuruskan oleh Kementerian Pendidikan Malaysiaberdasarkan peraturan-peraturan dan kriteria-kriteria tertentu.

Malaysia juga merupakan antara negara yang tertinggi menyediakan peruntukkan perbelanjaan pendidikan asas berbanding negara Singapura dan Jepun (KPM, 2014). Perdana Menteri Malaysia dalam belanjawan 
2013 menyatakan bidang pendidikan mendapat peruntukkan sebanyak 38.7 billion ringgit atau 21\% daripada keseluruhan belanjawan negara. Peruntukkan yang besar ini bagi memastikan polisi pendidikan negara, PPPM 2013-2025 mampu mengoptimumkan potensi murid (Muhamad Faizal A. Ghani, Norfariza Mohd Radzi, Simin Ghavifekr \& Husaina Banu Kenayatullah, 2014). Ia mengambarkan komitmen tinggi kerajaan dalam memberi pelbagai kemudahan kepada institusi pendidikan supaya dapat mewujudkan persekitaran kerja dan persekitaran belajar yang kondusif.

Justeru itu dapat dirumuskan bahawa sekolah di Malaysia mendapat input yang sama antara satu sekolah dengan sekolah yang lain. Dalam masa sama bidang pendidikan mendapat peruntukkan perbelanjaan yang cukup tinggi untuk program peningkatan pencapaian sekolah dan peningkatan kemahiran guru. Namun begitu pencapaian dalam peperiksaan awam khususnya SPM antara satu sekolah dengan sekolah yang lain dalam kategori yang sama masih lagi berbeza. Malah ada yang menunjukkan jurang pencapaian yang sangat luas antara satu sama lain.

Keputusan peperiksaan Sijil Pelajaran Malaysia (SPM) dari 2009-2013 (Laporan KPM, 2014), melaporkan bagi tahun 2013 sahaja lebih daripada 70\% sekolah yang berada di Band 5 dan 4. Ia tidak terkecuali dengan sekolah-sekolah menengah di bawah seliaan Pejabat Pendidikan Daerah Kota Bharu (PPD KB). Keputusan SPM 2015 umpamanya, masih terdapat sekolah yang menengah harian yang yang mendapat Gred Purata Sekolah (GPS) sekitar 4.0 dan 6.0 (PPD KB, 2015). Jurang pencapaian yang luas ini boleh menimbulkan persoalan, mengapa ia boleh terjadi sedemikian.

\section{PERNYATAAN MASALAH}

Komitmen guru dan kepuasan kerja guru boleh mempengaruhi pencapaian akademik pelajar ataupun prestasi sekolah. Kushman (1992) pula telah mengkaji dua dimensi komitmen iaitu komitmen terhadap organisasi dan komitmen terhadap pelajar dan mendapati kedua-duanya mempunyai pengaruh yang signifikan dengan pencapaian pelajar dan kepuasan kerja guru. Kajian Rahaman (2012) tentang komitmen guru dan kepuasan kerja guru di Bangladesh. Beliau merumuskan guru-guru sekolah swasta lebih tinggi komitmen berbanding sekolah awam dan juga mendapati jika kepuasan kerja guru dan komitmen guru meningkat maka prestasi sekolah turut meningkat.

Sehubungan dengan ini, komitmen guru-guru di sekolah yang berprestasi rendah menjadi suatu isu. Umum mengetahui, semua sekolah menengah harian mempunyai akses yang sama. Namun masih lagi wujud prestasi pencapaian sekolah yang tidak sama.

Kerajaan juga pada tahun 2015 telah memperkenalkan exit policy dalam sistem pendidikan negara. Melalui penilaian berdasarkan borang keberhasilan, guru-guru yang mendapat markah $60 \%$ ke bawah sebanyak dua kali dalam tempoh tiga tahun berturutan boleh ditamatkan perkhidmatan. Persoalannya setelah sekian lama baru polisi ini diperkenalkan dan berkemungkinan kerana tahap komitmen segelintir guru yang rendah sehinggakan kerajaan perlu mewujudkan polisi ini yang sudah tentu mengejutkan kakitangan awam khususnya warga pendidik. Polisi ini diwujudkan juga berkemungkinan bagi menyedarkan guru-guru yang berada dalam zon selesa dan bermasalah supaya sedar bahawa profesion perguruan sekarang ini tidak lagi terjamin seperti sebelum ini. Oleh itu, kajian ini cuba menyelidik komitmen guru di sekolah-sekolah yang terlibat sama ada persepsi ini mempunyai kebenaran atau sebaliknya.

Menurut Hallinger dan Heck (2010) dalam Arumugan Raman, Cheah Huey Mey, Yahya Don, Yaacob Daud, dan Rozlina Khalid (2015), guru yang mempunyai komitmen rendah akan menimbulkan masalah besar kepada pentadbiran sekolah dan ketuanya. Kajian oleh Nahed (2011), juga Aydogdu dan Asikgil (2011) mendapati terdapat hubungan signifikan positif antara kepuasan kerja guru dan komitmen guru terhadap sekolah. Justeru itu boleh dirumuskan, jika guru-guru mempunyai kepuasan kerja yang rendah akan menyebabkan komitmen mereka juga rendah. Seterusnya, mereka tidak ada motivasi dalam menjalankan tugas yang 
akhirnya menjejaskan prestasi kerja dan boleh menyebabkan prestasi sekolah turut merosot. Malah paling teruk akan memberi masalah kepada orang lain.

Oleh itu, timbul persoalan sama ada guru-guru di sekolah yang berprestasi tinggi mempunyai tahap komitmen yang tinggi dan tahap kepuasan kerja yang tinggi. Manakala guru-guru di sekolah yang berprestasi rendah pula tahap komitmen dan tahap kepusan kerja juga rendah. Semua persoalan ini perlu dijawab secara ilmiah. Justeru itu, satu kajian perlu dilakukan bagi merungkai persoalan tersebut.

\section{OBJEKTIF KAJIAN}

Objektif kajian ini ialah untuk mengenal pasti tahap komitmen guru dan tahap kepuasan kerja guru terhadap organisasi serta mengenal pasti dimensi komitmen guru yang paling tinggi tahap komitmennya. Seterusnya, ia juga bertujuan bagi mengenal pasti hubungan di antara komitmen guru dan kepuasan kerja guru terhadap organisasi yang dikaji.

\section{PERSOALAN KAJIAN}

Kajian ini juga membangkitkan beberapa persoalan bagi mencapai objektifnya. Persoalan yang dimaksudkan adalah sebagaimana berikut:

1. Apakah tahap komitmen guru mengikut dimensi terhadap organisasi di sekolah-sekolah menengah harian berprestasi tinggi dan berprestasi rendah di daerah Kota Bharu?

2. Apakah tahap kepuasan kerja guru di sekolah-sekolah menengah harian berprestasi tinggi dan berprestasi rendah di daerah Kota Bharu?

3. Adakah terdapat hubungan yang signifikan antara faktor-faktor demografi guru iaitu jantina dan umur dengan tahap komitmen guru terhadap organisasi di sekolah-sekolah menengah harian berprestasi tinggi dan berprestasi rendah di daerah Kota Bharu?

4. Adakah terdapat hubungan yang signifikan antara kepuasan kerja guru dan komitmen guru terhadap organisasi dalam kalangan guru-guru di sekolah-sekolah menengah harian berprestasi tinggi dan berprestasi rendah di daerah Kota Bharu.

\section{METODOLOGI KAJIAN}

Data bagi kajian ini diperoleh dengan menggunakan pendekatan secara kuantitatif melalui kaedah tinjauan rentasandwngan soal selidik terpiawai sebagai alat ukur kajian. Kajian ini melibatkan sekolah-sekolah menengah harian berprestasi tinggi dan berprestasi rendah di daerah Kota Bharu. Prestasi di sini merujuk kepada Gred Purata Sekolah (GPS) yang diperolehi dalam peperiksaan awam SPM bagi dua tahun berturutturut iaitu 2014 dan 2015. Perbandingan prestasi untuk dua tahun berturut-turut ini diperolehi daripada Unit Akademik Pejabat Pendidikan Daerah Kota Bharu.

Sehubungan itu, enam buah sekolah dipilih sebagai lokasi kajian. Tiga buah sekolah yang menduduki kelompok sepuluh teratas sebagai mewakili sekolah berprestasi tinggi. Manakala tiga buah sekolah yang menduduki kelompok sepuluh terbawah pula mewakili sekolah berprestasi rendah.Saiz populasi bagi enam buah sekolah adalah 409 orang. Berpandukan kaedah persampelan yang dicadangkan oleh Krejcie dan Morgan (1970), apabila saiz populasi dalam julat 400 hingga 420 maka julat sampel adalah antara 196 hingga 201. Oleh itu, pengkaji mengambil keputusan untuk menggunakan 200 sampel dalam kajian ini. Jadual 3.1 menunjukkan pengiraan bagaimana bilangan sampel bagi setiap sekolah ditentukan.

Jadual 3.1

Pengiraan Sampel Bagi Setiap Lokasi Kajian

\begin{tabular}{lllll}
\hline Sekolah & Bilangan Populasi/N (Orang) & Kaedah Pengiraan & Bilangan & Sampel/S \\
\hline
\end{tabular}




\begin{tabular}{llll}
\hline & & & (Orang) \\
\hline $\mathrm{A}$ & 81 & $(81 \div 409) \times 200=39.6$ & 40 \\
$\mathrm{~B}$ & 66 & $(66 \div 409) \times 200=32.3$ & 32 \\
$\mathrm{C}$ & 71 & $(71 \div 409) \times 200=34.7$ & 35 \\
$\mathrm{E}$ & 65 & $(65 \div 409) \times 200=31.7$ & 32 \\
$\mathrm{~F}$ & 77 & $(77 \div 409) \times 200=37.7$ & 38 \\
$\mathrm{G}$ & 49 & $(49 \div 409) \times 200=23.0$ & 23 \\
\hline & $\mathrm{N}=409$ & & $\mathrm{~S}=200$ \\
\hline
\end{tabular}

Instrumen kajian ini menggunakan Skala Komitmen Guru (SKG) (Lei Mee Thien, Nordin Abd Razak dan T. Ramayah, 2014) dan Job Satisfaction Survey (JSS) (Spector, 1997 dalam Crossman dan Harris, 2006) bagi memungut data tentang komitmen guru dan kepuasan kerja guru masing-masing. Kedua-dua instrumen menggunakan skala jenis likert 6 mata. Instrumen SKG mempunyai 13 item seperti ditunjukkan dalam Jadual 3.2. Manakala instrumen JSSmempunyai 36 item dengan sembilan sub skala.

Jadual 3.2

Senarai Item Bagi Dimensi Skala Komitmen Guru (SKG)

\begin{tabular}{lll}
\hline Dimensi Komitmen & Senarai Item & Bilangan \\
\hline Pelajar & 7,8 dan 10 & 3 \\
Pengajaran & 11,12 dan 13 & 3 \\
Sekolah & 2,3 dan 5 & 3 \\
Profesion & $1,4,6$ dan 9 & 4 \\
\hline Jumlah & & 13 \\
\hline
\end{tabular}

Setelah kajian rintis dilakukan, nilai kebolehpercayaan atau Cronbach's Alpha( $\alpha)$ bagi setiap dimensi dalam SKG ditunjukkan dalam Jadual 3.3.

Jadual 3.3

Nilai Kebolehpercayaan Mengikut Dimensi Bagi SKG

\begin{tabular}{lll}
\hline & Cronbach's Alpha/ $\alpha$ & Cronbach's Alpha Based on Standardized Items \\
\hline Pelajar & .64 & .66 \\
Pengajaran & .74 & .75 \\
Sekolah & .80 & .80 \\
Profesion & .79 & .77 \\
Keseluruhan & .76 & .76 \\
\hline
\end{tabular}

Menurut Hair et al. (2007), nilai alfa ( $\alpha$ ) yang melebihi 0.8 adalah baik, dan nilai antara 0.6 dan 0.7 boleh diterima manakala nilai kurang daripada 0.6 adalah lemah. Kesimpulannya, instrumen SKG ini boleh digunakan sebagai alat ukur kerana tiada nilai alfa kurang daripada 0.6 bagi setiap dimensi. Begitu juga dengan nilai kebolehpercayaan $(\alpha=0.89)$ bagi instrumen JSS adalah 'baik'.

Seterusnya, data kuantitatif kajian ini telah dianalisis secara deskriptif dan statistik inferensi dengan menggunakan SPSS versi 21.0. Tiga jenis ujian iaitu Ujian-t sampel bebas, Ujian ANOVA sehala dan Ujian Korelasi Pearson digunakan bagi bagi menjawab persoalan secara inferensi.

\section{DAPATAN KAJIAN}

Data yang diperolehi telah melalui ujian kenormalan bagi memastikan data berada dalam taburan normal. Data yang bertaburan normal merupakan prasyarat bagi kebanyakan teknik analisis statistik (Fauzi Hussin, 
Jamali \& Mohd Saifoul, 2014). Seterusnya, analisis dapatan kajian ini dibahagikan kepada dua bahagian iaitu dapatan deskriptif dan statistik inferensi.

1. Analisis Deskriptif

Kajian ini menggunakan interpretasi skor min yang telah dirumuskan oleh Mohd Najib (2003) bagi menentukan tahap komitmen guru dan tahap kepuasan kerja guru sepertimana dalam di bawah.

Interpretasi Skor Min Tahap

\begin{tabular}{ll}
\hline Julat Skor Min & Interpretasi \\
\hline $1.00-1.20$ & Sangat Rendah \\
$1.21-2.40$ & Rendah \\
$2.41-3.60$ & Sederhana \\
$3.61-4.80$ & Tinggi \\
$4.81-6.00$ & Sangat Tinggi \\
\hline
\end{tabular}

\subsection{Soalan Kajian Pertama}

Analisis Deskriptif Bagi Dimensi Komitmen Guru Dengan Prestasi Sekolah.

\begin{tabular}{llllll}
\hline Dimensi & Prestasi & Frekuensi & Min & $\begin{array}{l}\text { SisihanP } \\
\text { iawai }\end{array}$ & $\begin{array}{l}\text { Interpretasi } \\
\text { Tahap }\end{array}$ \\
\hline Terhadap pelajar & Tinggi & 92 & 3.81 & .74 & Tinggi \\
& Rendah & 92 & 3.72 & .84 & Tinggi \\
Terhadap pengajaran & Tinggi & 92 & 4.76 & .92 & Tinggi \\
& Rendah & 92 & 4.52 & .98 & Tinggi \\
Terhadap sekolah & Tinggi & 92 & 4.61 & .65 & Tinggi \\
& Rendah & 92 & 4.54 & .55 & Tinggi \\
Terhadap profesion & Tinggi & 92 & 4.55 & .59 & Tinggi \\
& Rendah & 92 & 4.55 & .56 & Tinggi \\
Keseluruhan & Tinggi & 92 & 4.44 & .47 & Tinggi \\
& Rendah & 92 & 4.35 & .40 & Tinggi \\
\hline
\end{tabular}

\section{$2.2 \quad$ Soalan Kajian Kedua}

Analisis Deskriptif Bagi Kepuasan Kerja Guru Dengan Prestasi Sekolah.

\begin{tabular}{lllcll}
\hline & $\begin{array}{l}\text { Prestasi } \\
\text { Sekolah }\end{array}$ & Frekuensi & Min & $\begin{array}{l}\text { Sisihan } \\
\text { Piawai }\end{array}$ & $\begin{array}{l}\text { InterpretasiTa } \\
\text { hap }\end{array}$ \\
\hline Kepuasan Kerja & Tinggi & 92 & 3.90 & .44 & Tinggi \\
& Rendah & 92 & 3.79 & .35 & Tinggi \\
\hline
\end{tabular}

\section{Analisis Inferensi}

$\mathrm{H}_{0} 1$ : Tidak terdapat perbezaan yang signifikan dalam tahap komitmen guru mengikut dimensi terhadap organisasi antara sekolah menengah harian berprestasi tinggi dengan berprestasi rendah.

Keputusan Ujian-t Sampel Bebas Dimensi Komitmen Guru Berdasarkan Prestasi Sekolah

\begin{tabular}{llllllll}
\hline Dimensi & & \multicolumn{4}{l}{$\begin{array}{l}\text { Levene's } \\
\text { Equality of Variances }\end{array}$} & \multicolumn{2}{c}{ for } \\
\cline { 3 - 7 } & & $\mathrm{F}$ & Sig. & $\mathrm{t}$ & $\mathrm{df}$ & Sig. (2-tailed) \\
\hline $\begin{array}{l}\text { Komitmen } \\
\text { terhadap }\end{array}$ & $\begin{array}{l}\text { Equal } \\
\text { assumed }\end{array}$ & variances & .219 & .64 & .714 & 182 & .48
\end{tabular}




\begin{tabular}{|c|c|c|c|c|c|c|}
\hline pelajar & $\begin{array}{l}\text { Equal variances not } \\
\text { assumed }\end{array}$ & & & .714 & 178.64 & .48 \\
\hline $\begin{array}{l}\text { Komitmen } \\
\text { terhadap }\end{array}$ & $\begin{array}{l}\text { Equal } \\
\text { assumed }\end{array}$ & .052 & .82 & 1.766 & 182 & .08 \\
\hline pengajaran & $\begin{array}{l}\text { Equal variances not } \\
\text { assumed }\end{array}$ & & & 1.766 & 181.29 & .08 \\
\hline $\begin{array}{l}\text { Komitmen } \\
\text { terhadap }\end{array}$ & $\begin{array}{l}\text { Equal } \\
\text { assumed }\end{array}$ & 2.605 & .11 & .817 & 182 & .42 \\
\hline sekolah & $\begin{array}{l}\text { Equal variances } \\
\text { assumed }\end{array}$ & & & .817 & 177.97 & .415 \\
\hline $\begin{array}{l}\text { Komitmen } \\
\text { terhadap }\end{array}$ & $\begin{array}{l}\text { Equal } \\
\text { assumed }\end{array}$ & .106 & .75 & .000 & 182 & 1.00 \\
\hline profesion & $\begin{array}{l}\text { Equal variances not } \\
\text { assumed }\end{array}$ & & & .000 & 181.69 & 1.00 \\
\hline
\end{tabular}

${ }^{*} \mathrm{p}<.05$

Ujian-t menunjukkan nilai signifikan (2-tailed), p > .05. Kesimpulannya adalah tidak terdapat perbezaan yang signifikan dalam tahap komitmen guru mengikut dimensi terhadap organisasi antara sekolah menengah harian berprestasi tinggi dengan berprestasi rendah. Oleh itu, hipotesis nol gagal ditolak.

$\mathrm{H}_{0} 2$ : Tidak terdapat perbezaan yang signifikan dalam tahap kepuasan kerja guru antara sekolah menengah harian berprestasi tinggi dengan berprestasi rendah.

Keputusan Ujian-t Sampel Bebas Kepuasan Kerja Guru Berdasarkan Prestasi Sekolah

\begin{tabular}{lllllll}
\hline & & \multicolumn{2}{l}{$\begin{array}{l}\text { Levene's } \\
\text { Equality of Variances }\end{array}$} & \multicolumn{3}{l}{ T-test for Equality of Means } \\
\cline { 2 - 7 } & & $\mathrm{F}$ & Sig. & $\mathrm{t}$ & $\mathrm{df}$ & Sig. (2-tailed) \\
\hline $\begin{array}{l}\text { Kepuasan } \\
\text { Kerja guru }\end{array}$ & $\begin{array}{l}\text { Equal variances } \\
\text { assumed }\end{array}$ & 2.310 & $.13^{*}$ & 1.912 & 182 & $.06^{*}$ \\
& $\begin{array}{l}\text { Equal variances } \\
\text { not assumed }\end{array}$ & & & 1.912 & 172.89 & $.06^{*}$ \\
\hline
\end{tabular}

${ }^{*} \mathrm{p}<.05$

Analisis $t$-test for Equality of Means menunjukkan nilai signifikan (2-tailed), $\mathrm{p}=.06>.05$. Ini menunjukkan tidak terdapat perbezaan yang signifikan dalam tahap kepuasan kerja guru antara sekolah menengah harian berprestasi tinggi dengan sekolah menengah harian berprestasi rendah. Maka, hipotesis nol gagal ditolak.

$\mathrm{H}_{0} 3$ : Tidak terdapat perbezaan yang signifikan dalam faktor demografi jantina guru dengan komitmen guru terhadap organisasi di sekolah menengah harian berprestasi tinggi dan berprestasi rendah.

Apabila pemboleh ubah bebas adalah data norminal dan satu pemboleh ubah bersandar yang selanjar, maka ujian-t sampel bebas adalah lebih sesuai digunakan (Othman Talib, 2013).

\section{Keputusan Ujian-t Sampel Bebas Komitmen Guru Berdasarkan Jantina Bagi Sekolah Berprestasi Tinggi}

\begin{tabular}{lllllll}
\hline & \multicolumn{6}{c}{$\begin{array}{l}\text { Levene's } \\
\text { Equality of Variances }\end{array}$} \\
\cline { 2 - 8 } & \multicolumn{2}{c}{$\mathrm{F}$} & Sig. & $\mathrm{t}$ & $\mathrm{df}$ & Sig.(2-tailed) \\
\hline $\begin{array}{l}\text { Komitmen } \\
\text { Guru }\end{array}$ & $\begin{array}{l}\text { Equal variances } \\
\text { assumed } \\
\text { Equal variances not }\end{array}$ & .075 & $.78^{*}$ & -1.303 & 90 & $.20^{*}$ \\
\hline
\end{tabular}

868 
assumed

$* \mathrm{p}<.05$

Dapatan ujian-t menunjukkan tidak terdapat perbezaan yang signifikan komitmen guru berdasarkan jantina di sekolah berprestasi tinggi, $\mathrm{t}(90)=-1.303, \mathrm{p}=.20>.05$. Oleh itu, keputusan ini gagal menolak hipotesis nol.

Keputusan Ujian-t Sampel Bebas Komitmen Guru Berdasarkan Jantina Bagi Sekolah Berprestasi Rendah

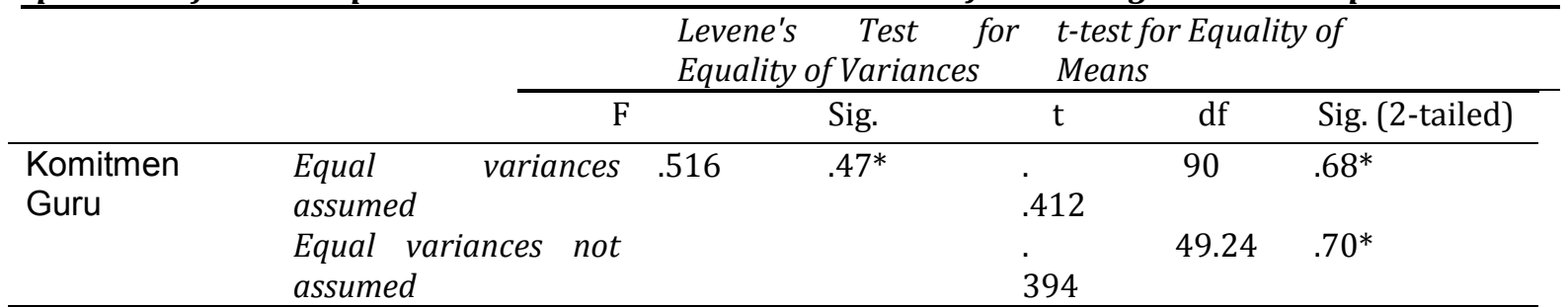

*p $<.05$

Ujian-t menunjukkan tidak terdapat perbezaan yang signifikan komitmen guru berdasarkan jantina di sekolah berprestasi rendah, $\mathrm{t}(90)=.412, \mathrm{p}=.68>.05$. Oleh itu, hipotesis nol juga gagal ditolak.

$\mathrm{H}_{0} 4$ : Tidak terdapat perbezaan yang signifikan dalam faktor demografi umur guru dengan komitmen guru terhadap organisasi di sekolah menengah harian berprestasi tinggi dan berprestasi rendah.

Othman Talib (2013) menyatakan ujian ANOVA sangat popular bagi membandingkan lebih daripada dua kumpulan bagi pemboleh ubah bebas yang sama secara serentak dengan satu pemboleh ubah bersandar.

Keputusan Ujian ANOVA Sehala Perbandingan Komitmen Guru Berdasarkan Demografi Umur Bagi Sekolah Berprestasi Tinggi

\begin{tabular}{llllll}
\hline & Sum of Squares & $\mathrm{df}$ & Mean Square & $\mathrm{F}$ & Sig. \\
\hline Antara kumpulan & .109 & 4 & .027 & .121 & $.98^{*}$ \\
Dalam kumpulan & 19.653 & 87 & .226 & & \\
Jumlah & 19.762 & 91 & & & \\
\hline
\end{tabular}

${ }^{*} \mathrm{p}<.05$

Analisis ujian ANOVA sehala memberi hasil dapatan yang tidak signifikan, $F(4)=.121, \mathrm{p}>.05$, di mana tidak terdapat perbezaan yang signifikan dalam faktor demografi umur guru dengan komitmen guru di sekolah berprestasi tinggi. Oleh itu, hipotesis nol gagal ditolak.

Keputusan Ujian ANOVA Sehala Perbandingan Komitmen Guru Berdasarkan Demografi Umur Bagi Sekolah Berprestasi Rendah

\begin{tabular}{llllll}
\hline & Sum of Squares & $\mathrm{df}$ & Mean Square & $\mathrm{F}$ & Sig. \\
\hline Antara kumpulan & .542 & 4 & .135 & .845 & $.50^{*}$ \\
Dalam kumpulan & 13.937 & 87 & .160 & & \\
Jumlah & 14.479 & 91 & & & \\
\hline
\end{tabular}

*p $<.05$

Dapatan ujian ANOVA sehala pula adalah tidak signifikan dengan nilai $F(4)=.845, p>.05$. Ini menunjukkan tidak terdapat perbezaan yang signifikan dalam faktor demografi umur guru dengan komitmen guru di sekolah beprestasi rendah dan kesimpulannya, hipotesis nol gagal ditolak.

$\mathrm{H}_{0} 5$ : Tidak terdapat hubungan yang signifikan antara komitmen guru terhadap organisasi dan kepuasan kerja guru di sekolah menengah harian berprestasi tinggi dan berprestasi rendah. 
Keputusan Ujian Korelasi Bagi Sekolah Berprestasi Tinggi

\begin{tabular}{llll}
\hline & & Komitmen guru & Kepuasan kerja \\
\hline Komitmen guru & Pearson Correlation & 1 & $.44^{* *}$ \\
& Sig. (2-tailed) & & .00 \\
& $\mathrm{~N}$ & 92 & 92 \\
Kepuasan kerja guru & Pearson Correlation & $.44^{* *}$ & 1 \\
& Sig. (2-tailed) & .00 & \\
& $\mathrm{~N}$ & 92 & 92 \\
\hline
\end{tabular}

**. Correlation is significant at the 0.01 level (2-tailed).

Analisis menunjukkan nilai korelasi, $r=.44$, ia memberi interpretasi bahawa wujud hubungan yang sederhana (Hair at al., 2007) antara komitmen guru dengan kepuasan kerja guru. Manakala nilai signifikan, $p$ $=.00<.05$, dapatan ini menunjukkan wujud hubungan yang signifikan antara kepuasan kerja guru dengan komitmen guru di sekolah berprestasi rendah. Walaupun hubungan ini dinilai hanya pada tahap sederhana. Oleh itu, hipotesis nol berjaya ditolak.

Keputusan Ujian Korelasi Bagi Sekolah Berprestasi Rendah

\begin{tabular}{llll}
\hline & & Komitmen guru & Kepuasan kerja \\
\hline Komitmen guru & Pearson Correlation & 1 & $.39^{* *}$ \\
& Sig. (2-tailed) & & .00 \\
& $\mathrm{~N}$ & 92 & 92 \\
\multirow{4}{*}{ Kepuasan kerja } & Pearson Correlation & $.39^{* *}$ & 1 \\
& Sig. (2-tailed) & .00 & 92 \\
& $\mathrm{~N}$ & 92 &
\end{tabular}

Keputusan ujian bagi sekolah berprestasi rendah menunjukkan nilai korelasi, $r=.39$ yang memberi tafsiran bahawa wujud hubungan yang kecil tetapi pasti (Hair at al., 2007) antara kepuasan kerja guru dengan komitmen guru di sekolah berprestasi rendah. Dapatan kajian juga menunjukkan nilai $\mathrm{p}=.00$, yang bermaksud terdapat hubungan yang signifikan antara komitmen guru terhadap kepuasan kerja guru di sekolah berprestasi rendah. Oleh itu, hipotesis nol juga berjaya ditolak.

\section{PERBINCANGAN}

Tahap bagi semua empat dimensi komitmen guru bagi semua sekolah adalah tinggi. Begitu juga apabila ujian lanjutan menggunakan ujian-t sampel bebas melalui analisis inferensi menunjukkan bahawa tidak terdapat perbezaan yang signifikan dalamtahap komitmen guru mengikut dimensi terhadap sekolah.

Namun, min skor mengikut item yang diperolehi mengambarkan guru-guru di sekolah menengah berprestasi tinggi mempunyai tahap tinggi pada dimensi komitmen terhadap pengajaran. Ia dibuktikan dengan item ke13 iaitu "Keputusan terbaik yang pernah saya buat adalah untuk menjadi guru" mencatat min skor paling tinggi. Dengan kata lain guru-guru lebih menumpukan kepada pengajaran dan pembelajaran di dalam kelas. Komitmen terhadap pengajaran ini membawa kepada pencapaian tinggi akademik pelajar kerana GPS ketigatiga sekolah yang dikaji mendapat gred baik iaitu antara 3.00 hingga 4.00 .

Dapatan ini selari dengan kajian Tyree (1996) menyatakan guru-guru yang komited terhadap pengajaran juga sanggup berusaha lebih gigih menyediakan pengajaran berkesan dan bersedia memberi tumpuan yang 
lebih kepada pelajar. Kajian dalam negara oleh Norazlinda Saad dan Surendran Sankaran (2013) terhadap sekolah menengah kebangsaan berpencapaian tinggi di seluruh negeri Kedah mendapati peningkatan kadar komitmen akan meningkatkan keberkesanan dan menunjukkan prestasi akademik yang tinggi.

Berbeza dengan sekolah berprestasi rendah, skor min mengikut item menunjukkan nilai paling tinggi bagi dimensi komimen terhadap profesion. Ini dibuktikan dengan item pertama iaitu "Selalunya, saya rasa sukar untuk bersetuju dengan polisi organisasi ini dalam hal-hal penting yang berkaitan dengan pekerjanya" merekodkan antara nilai min paling tinggi. Manakala nilai min bagi dimensi yang paling rendah adalah komitmen terhadap pelajar. Oleh itu, pencapaian akademik pelajar yang rendah mempunyai kewajarannya. Tahap komitmen kepada pelajar yang rendah mungkin memberi kesan kepada pencapaian pelajar, kurang simpati terhadap pelajar, dan kurang toleransi (Firestone \& Pennell, 1993; Louis, 1998 dalam Lei Mee Thien, Nordin Abd Razak,\& T. Ramayah, 2014).

Bagi min keseluruhan komitmen guru di kedua-dua kategori sekolah berada pada tahap tinggi. Namun, apa yang berlaku prestasi pencapaian akademik pelajar tidak selari dengan tahap komitmen guru yang tinggi di sekolah berprestasi rendah. Dapatan ini menunjukkan ada faktor peramal lain yang mempengaruhi pencapaian akademik pelajar dan faktor budaya sekolah berkemungkinan merupakan peramal terhadap pencapaian sekolah. Ia dibuktikan dengan kajian oleh Yaakob Daud (2007), antara dapatan kajian beliau adalah budaya sekolah positif secararelatif lebih dipraktikkan di sekolah berpencapaian tinggi berbanding di sekolah berpencapaian rendah dan budaya sekolah positif mempunyai hubungan yang positif dengan pencapaian akademik pelajar.

Oleh itu, faktor demografi iaitu jantina dan umur guru yang mungkin menyumbang kepada komitmen guru yang tinggi dalam kajian ini. Di mana responden guru perempuan adalah seramai 63 orang atau 68.5\% berbanding guru lelaki hanya 29 orang atau 31.5\%. Kajian oleh Oshagbemi (2000) tentang perbezaan jantina dengan komitmen kerja pensyarah universiti di United Kingdom mendapati pensyarah perempuan lebih mempunyai komitmen berbanding pensyarah lelaki. Selari dengan Klag dan Bradley (2004) yang mendapati bahawa skor komitmen guru perempuan adalah lebih tinggi berbanding dengan guru lelaki dan di sokong oleh Suzyanty et al. (2005).

Dapatan kajian tentang kepuasan kerja guru di semua sekolah yang terlibat berada pada tahap tinggi. Tiada perbezaan yang signifikan dalam tahap kepuasan kerja guru antara sekolah yang berprestasi tinggi dengan yang berprestasi rendah.

Namun begitu, subskala bagi kepuasan kerja terhadap prosedur operasi kedua-dua kategori sekolah mencatatkan tahap sederhana. Contohnya item dalam subskala ini adalah "Banyak peraturan dan prosedur menjadikan kerja lebih sukar" dan "Bebanan kerja saya terlalu banyak". Oleh itu, ia mengambarkan bebanan tugas dan kerenah birokrasi telah memberi tekanan kerja dan seterusnya menurunkan tahap kepuasan kerja guru yang menyebabkan subskala ini menghasilkan interpretasi yang paling lebih rendah berbanding subskala lain. Tekana yang berlebihan atau yang tidak baik berkemungkinan mempunyai kesan negatif ke atas prestasi dan komitmen pekerja.

Azrul Hisyam Abdul Manaf (2009) menyatakan bebanan tugas merupakan antara faktor penyebab kepada guru menghadapi tekanan. Dapatan yang sama juga diperolehi oleh Ooi Chew Hong dan Aziah Ismail (2015) dalam kajian mereka terhadap perbandingan tekanan kerja guru di sekolah kebangsaan dan sekolah jenis kebangsaan di daerah barat daya negeri Pulau Pinang. Beliau merumuskan bebanan tugas menjadi faktor kedua paling tinggi memberi sumbangan terhadap tekanan kerja guru selepas faktor disiplin murid.

Hasil kajian juga menunjukkan tidak terdapat perbezaan yang signifikan dalam faktor demografi guru dengan komitmen guru terhadap organisasi di sekolah menengah harian berprestasi tinggi dan berprestasi rendah. Dengan kata lain, faktor jantina guru tidak mempengaruhi komitmen guru sama ada di sekolah yang 
berprestasi rendah atau sekolah yang berprestasi tinggi. Dapatan ini selari dengan Sezgin (2008) yang menyatakan faktor kedua-dua jantina guru memberi sumbangan yang ketara terhadap komitmen. Kemudian disokong oleh kajian yang dilakukan Nahid (2011) terhadap guru-guru Bahasa Inggeris di sekolah menengah. Beliau merumuskan tidak terdapat perbezaan yang signifikan antara guru-guru Bahasa Inggeris berdasarkan jantina dengan komitmen terhadap organisasi.

Bagi faktor umur pula, dapatan kajian menunjukkan tidak terdapat perbezaan yang signifikan dalam faktor umur guru dengan komitmen guru di kedua-dua kategori sekolah. Ia bermaksud semua guru memberi komitmen yang tinggi tanpa mengira kategori umur. Brockner dan Grover (1998) yang menyatakan tidak terdapat hubungan antara umur pekerja dan komitmen organisasi. Begitu juga dengan Nahid (2011) dalam kajian beliau terhadap guru-guru di sekolah menengah mendapati tidak terdapat perbezaan yang signifikan di kalangan kumpulan umur yang berbeza mengenai komitmen terhadap organisasi.

Seterurusnya, dapatan kajian menunjukkan terdapat hubungan positif yang signifikan di antara kepuasan kerja guru dengan komitmen guru di kedua-dua jenis sekolah. Namun, sedikit berbeza pada aras hubungan yang wujud. Sekolah berprestasi tinggi menunjukkan hubungan pada aras sederhana $(r=.44)$ manakala sekolah berprestasi rendah menunjukkan hubungan pada aras yang kecil tetapi masih ada hubungan (Hair at al., 2007). Dapatan ini selari dengan kajian oleh Sarimah Ismail dan Faridatul Akmar Talip (2010) terhadap staf akademik di Jabatan Pendidikan Teknikal dan Kejuruteraan (JPTK) yang menunjukkan tahap kepuasan kerja adalah sederhana. Ia wujud kerana beban tugas terlalu banyak yang dipertanggungjawabkan. Apabila kepuasan kerja menurun atau kerja tidak lagi menyeronokkan maka sudah tentu komitmen pekerja akan turut berkurangan. Situasi ini pernah dikaji oleh Noorhafeza Herliani Adey dan Ferlis Bahari (2010) terhadap pekerja Jabatan Perkhidmatan Awam di negeri Sabah. Beliau menyatakan terdapat hubungan positif dan signifikan antara kepuasan kerja dan komitmen organisasi.

\section{RUMUSAN}

Saban hari pelbagai isu yang melingkari golongan pendidik terpampang di dada-dada akhbar. Pelbagai perkara yang negetif tentang guru di war-warkan. Masyarakat juga kurang menghormati guru dan sering menyalahkan guru jika terjadi perkara yang tidak diingini terhadap pelajar atau anak mereka. Bekas Ketua Pengarah Pelajaran,Tan Sri Alimuddin Mohd. Dompernah berkata, "Semua masyarakat patut menghormati guru kerana mereka bukan sahaja menyampaikan ilmu pengetahuan malah mendidik anak bangsa untuk menjadi seorang insan berguna," (Utusan Malaysia, 14 Januari 2013). Ungkapan ini membuktikan perasaan hormat masyarakat terhadap golongan pendidik benar-benar wujud.

Oleh itu, kajian ini serba sedikit telah menyangkal pelbagai persepsi negatif masyarakat terhadap golongan pendidik. Walaupun pelbagai isu, tomahan dan pandangan yang sinis namun hasil kajian menunjukkan komitmen guru terhadap sekolah secara umumnya masih tinggi tidak sepertimana yang disangkakan. Sama ada guru tersebut bertugas di sekolah berprestasi tinggi ataupun sekolah yang berprestasi rendah.

Namun banyak kajian menunjukkan kepuasan kerja dan komitmen guru masih lagi menunjukkan hasil pelbagai. Buktinya, kepuasan kerja guru dan komitmen kerja guru dalam kajian ini menunjukkan terdapat hubungan yang signifikan tetapi aras sederhana (sekolah berprestasi tinggi) dan lemah (sekolah berprestasi rendah) terutamanya apabila dilihat pada dimensi-dimensi tertentu. Dengan adanya tindakan yang proaktif daripada pihak kerajaan diharap dapat mengatasi masalah ini.

Timbalan perdana menteri pernah meminta kementerian pendidikan meneliti cadangan penggubalan Akta Perlindungan Guru bagi melindungi golongan pendidik ketika bertugas (Utusan Malaysia, 7 Ogos 2016). Kementerian juga dengan sedaya upaya telah mengurangkan masalah "guru duka lara" dan juga telah memberi hadiah satu kenaikkan tangga gaji pada Julai 2016. Dengan pelbagai tindakan ini, semoga hasrat 
murni kerajaan untuk memartabatkan profesion pendidikan dan menjadikan guru-guru lebih komited dalam menjalankan tugas demi melaksanakan PPPM tercapai.

\section{RUJUKAN}

Abdul Ghafar Mohd Noor.(2003). Pembangunan Penyelidikan. Johor: Penerbit Universiti Teknologi Malaysia.

Alf Crossman, \& Penelope Harris (2006). Job satisfaction of secondary school teachers. Educational Management Administration \& Leadership, 29-46. doi: 10.1177/1741143206059538.

Alimuddin, Mohamad Dom. (2013). Hormati Guru Jangan Perlekeh. http://ww1.utusan.com.my dimuat turun pada 8 Ogos 2016.

Arumugan Raman, Cheah Huey Mey, Yahya Don, Yaakob Daud, \& Rozlina Khalid. (2015). Relationship between principals' transformational leadership style and secondary school teacher' commitment. Asian Social Science, 11(15), 221-228.

Azrul Hisham Abdul Manaf. (2009). Faktor-faktor tekanan dan kesannya kepada guru sekolah menengah kebangsaan: Satu kajian di daerah timur laut, Pulau Pinang. Tesis Sarjana. Universiti Utara Malaysia.

Brockner, J. \& Grover, S. L. (1998). Predictors of survivor's job involvement following layoffs: A field study. Journal of Applied Psychology, 73(3),436-442.

Fauzi Hussin, Jamal Ali \& Mohd Saifoul Zamzuri Noor. (2014). Kaedah penyelidikan \& analisis data SPSS. Sintok: UUM Press.

Feredun Sezgin. (2008). Relationships between teacher organizational commitment, psychological hardiness and some demographic variables in Turkish primary schools. Journal of Educational Administration, $47(5), 630-651$.

Hair, J. F., Money, A.H., Samouel, P., \& Page, M. (2007).Research method for business. West Sussex: John Wiley \& Sons Ltd.

Kementerian Pelajaran Malaysia (2012). Pelan Pembangunan Pendidikan Malaysia (2013-2025) Edisi pelancaran. Putrajaya.

Kementerian Pelajaran Malaysia. (2014). Unit Data, Bahagian Pendidikan Khas: Putrajaya.

Klag, S. and Bradley, G. (2004). The role of hardiness in stress and illness: an exploration of the effect of negative affectivity and gender. British Journal of Health Psychology, 9,137-161.

Krejcie, R. V., \& Morgan, D. W. (1970). Determine sample size for research education and psychological, 30, 607610.

Kushman, J.W. (1992). The organizational dynamics of teacher workplace commitment: A study of urban elementary and middle schools. Educational Administration Quarterly, 28(1), 5-42.

Lei Mee Thien, Nordin Abd Razak,\& T. Ramayah. (2014). Validating teacher commitment scale using a Malaysian sample. Regional Centre for Educationin Science and Mathematics. 1-9. doi: $10.1177 / 2158244014536744$

Likert, R. (1961). The new pattern in management. New York: Mc Graw-Hall.

Mohd Najib Abdul Ghafar. (2003). Kaedah penyelidikan pendidikan. Kuala Lumpur: Dewan Bahasa dan Pustaka.

Muhammad Faizal A. Ghani, Norfariza Mohd Radzi, Simin Ghavifekr, \& Husaina Banu Kenayatullah. (2014). Pengurusan disiplin murid di sekolah kawasan bandar dan luar bandar; Perspektif pemimpin sekolah. Jurnal Kepimpinan Pendidikan, 1(1),7-40.

Nahid Naderi Anari. (2011). Teachers: emotional intelligence, job satisfaction, and organizational commitment. Journal of Workplace Learning. 24(4), 256-269.

Noorhafeza Herliani Adey,\& Ferlis Hj. Bahari (2010). Hubungan antara kecerdasan emosi, kepuasan kerja dan komitmen terhadap organisasi. Jurnal Kemanusiaan, 16.62-78.

Norazlinda Saad,\& Surendren Sankaran. (2013). Pengaruh Sikap Guru Terhadap Pembuatan Keputusan ke Atas Komitmen Guru di Sekolah: Galakan Pengetua Sebagai Pengantara. Malaysian Journal of Learning and Instruction, 10, 271-294. 
Ooi Chew Hong,\& Aziah Ismail. (2015). Sokongan pihak pengurusan sekolah terhadap tekanan kerja guru di sekolah kebangsaan dan sekolah jenis kebangsaan cina. Jurnal Kepimpinan Pendidikan, 2(2),42-57.

Othman Talib. (2013). Asas penulisan tesis, penyelidikan dan statistik. Serdang: Universiti Putra Malaysia Press.

Rokiah, A. (2016). Teliti Akta Perlindungan Guru.http://www.utusan.com.my, dimuat turun pada 8 Ogos 2016.

Saidur Rahaman, H. M. (2012). Organizational commitment, perceived organizational support, and job satisfaction among school teachers: comparing public and private sectors in Bangladesh. South Asian Journal of Management, 19(3),7-17.

Sarimah Ismail, \& Faridatul Akmar Talip. (2010). Kepuasan bekerja staf akademik jabatan pendidikan teknikal dan kejuruteraan, fakulti pendidikan, Universiti Teknologi Malaysia, Skudai. Jabatan Pendidikan Teknikal dan Kejuruteraan, Fakulti Pendidikan, Universiti Teknologi Malaysia, Skudai. 1-7.

Sinem Aydogdu,\& Baris Asikgil. (2011). An empirical study of the relationship among job satisfaction, organizational commitment and turnover intention. International Review of Management and Marketing, 1(3), 43-53.

Suzyanty Mohd Shokory, Wan Salmuni Wan Mustaffa, \& Norsamsinar Samsudin. (2005). Kepuasan kerja kakitangan akademik: Satu perbandingan Jantina. Kertas Kerja Bagi Pembentangan Persidangan Psikologi Malaysia.

Tyree, A.K. (1996). Conceptualising and measuring commitment to high school teaching. Journal of Educational Research, 89(5), 295-304.

Yaakob Daud. (2007). Budaya sekolah rendah: Hubungannya dengan kepimpinan, komitmen organisasi dan pencapaian akademik.Tesis Ijazah Doktor Falsafah tidak diterbitkan. Universiti Sains Malaysia, Pulau Pinang. 